\title{
Self-expanding stents and aortoiliac occlusive disease: a review of the literature
}

This article was published in the following Dove Press journal:

Medical Devices: Evidence and Research

2 May 2014

Number of times this article has been viewed

\author{
Joost A Bekken' \\ Hidde Jongsma' \\ Jean-Paul PM de Vries² \\ Bram Fioole' \\ 'Department of Vascular Surgery, \\ Maasstad Hospital, Rotterdam, the \\ Netherlands; ${ }^{2}$ Department of Vascular \\ Surgery, St Antonius Hospital, \\ Nieuwegein, the Netherlands
}

Correspondence: Bram Fioole Maasstad Hospital, Maassstadweg 21, 3079 DZ Rotterdam, the Netherlands $\mathrm{Tel}+31 \quad 1029 \mid 1247$

Email fiooleb@maasstadziekenhuis.nl

\begin{abstract}
The treatment of symptomatic aortoiliac occlusive disease has shifted from open to endovascular repair. Both short- and long-term outcomes after percutaneous angioplasty and stenting rival those after open repair and justify an endovascular-first approach. In this article, we review the current endovascular treatment strategies in patients with aortoiliac occlusive disease, indications for primary and selective stenting in the iliac artery, and physical properties and future perspectives of self-expanding stents.
\end{abstract}

Keywords: endovascular, self-expanding stent, aortoiliac

\section{Introduction}

The prevalence of peripheral arterial disease (PAD) in the US is more than $4 \%$ among adults aged 40 years and over. PAD increases dramatically with age and the prevalence exceeds $14 \%$ among those aged 70 years or over. ${ }^{1}$ One subset of PAD is aortoiliac occlusive disease (AIOD), defined as any stenosis or occlusion from the distal aorta to the common femoral artery (CFA). Conventional surgical revascularization of AIOD is associated with excellent long-term patency rates. ${ }^{2,3}$ However, open repair is also associated with a significantly longer hospital stay and higher complication rates and inpatient costs, compared with endovascular treatment. ${ }^{4}$ The TransAtlantic Intersociety Consensus (TASC) II, published in 2007, recommends endovascular therapy for straightforward AIOD (TASC A lesions) and surgery for complex AIOD (TASC D lesions). ${ }^{5}$ However, due to the rapid development of endovascular techniques and improved competence, experienced centers advocate an "endovascular first" approach. In recent years, endovascular treatment has become widespread and is the preferred method of treatment nowadays for lower extremity arterial obstructions. ${ }^{6}$

Endovascular treatment of AIOD consists of percutaneous transluminal angioplasty (PTA) with or without stenting. In a meta-analysis of six PTA studies (1,300 patients) and eight PTA and stent studies (816 patients), additional stenting was associated with an increased technical success rate and improved long-term patency. ${ }^{7}$ The results of endovascular treatment of AIOD have been described in multiple publications. Technical success and both short- and long-term patency rates have been satisfactory, even in challenging lesions. ${ }^{8,9}$ These results justify an endovascular-first approach for symptomatic AIOD treatment. 


\section{Overview of current endovascular treatment for AIOD \\ Primary versus selective stenting}

The Dutch Iliac Stent Trial enrolled 279 patients with intermittent claudication on the basis of iliac artery stenosis of $>50 \%$. The study randomly assigned 143 patients to direct stent placement (group I) and 136 to primary angioplasty, with selective stent placement in case of a residual mean pressure gradient $>10 \mathrm{mmHg}$ across the treated lesion (group II). The primary endpoint was clinical success, defined as improvement of at least one clinical category in the Fontaine classification. ${ }^{5}$ In group II, stents were selectively placed in $43 \%$ of the patients. Less than $10 \%$ of patients were treated for iliac artery occlusions and the stenosis length was $<2 \mathrm{~cm}$ in 56\% patients. Most lesions corresponded to TASC A and B lesions. Clinical success, cumulative patency, and reintervention rates at 2 years were similar between the groups. ${ }^{10}$ Longterm results (after 5-8 years) showed a better clinical outcome in patients with PTA and selective stenting in the iliac artery. Iliac patency, ankle-brachial index, and quality of life did not support a difference between groups. ${ }^{11}$

More recent studies showed that primary stenting has significant benefits over angioplasty alone in TASC C and D aortoiliac lesions. In a nonrandomized series of 151 patients with iliac stenosis, a total of 110 consecutive patients (149 lesions) underwent primary stenting. The results were compared with 41 patients (41 lesions) who had PTA followed by selective stenting for suboptimal PTA. The overall early clinical success rate was superior for the primary stent group (Figure 1). For TASC A and B lesions, the initial and late clinical success rates were comparable but were inferior in selective stenting for TASC C and D lesions. ${ }^{12}$

A recent meta-analysis of 16 reports including 958 patients with endovascular treatment of TASC C and D aortoiliac arterial lesions found better patency rates for primary stenting than for selective stenting. ${ }^{8}$

The Stents Versus Angioplasty for the Treatment of Iliac Artery Occlusions (STAG) trial randomly assigned 112 patients with an iliac occlusion to PTA or primary stent placement. PTA was performed in 55 patients and primary stenting in 57 . Technical success in the primary stenting group was higher (98\% vs $84 \%$ ) and major complications (predominantly distal embolization) occurred less frequently ( $5 \%$ vs $20 \%$ ) compared with PTA. Patency rates did not differ after 1 and 2 years. ${ }^{13}$

\section{Predictors of success or failure}

Independent predictors of iliac endovascular intervention success or failure have been described in multiple publications.
The presence of two-vessel femoral runoff or at least two patent below-the-knee vessels, or both, is associated with improved iliac artery primary patency. ${ }^{14}$ Poor outflow requiring a bypass is associated with decreased iliac artery primary patency rates. ${ }^{3}$ In another study, iliac PTA and stenting, combined with an untreated superficial femoral artery stenosis $>50 \%$ resulted in a decreased primary patency rate. ${ }^{15}$

The presence of an iliac artery occlusion is considered an independent risk factor for patency loss. ${ }^{16}$ However, similar results after treatment of iliac stenoses and occlusions have been published. In a series of 73 patients including 76 occluded iliac arteries (33 common, 34 external, and nine both) the primary patency was $79 \%$ at 1 year and $69 \%$ at 3 years. ${ }^{17}$ In a prospective series of 223 patients with AIOD, endovascular treatment was performed for iliac occlusion in 109 patients and for iliac stenosis in 114 patients. No differences were observed in the complication rate or in short- and long-term patency rates. ${ }^{18}$

Other predictors for decreased primary patency include diabetes mellitus, ${ }^{3}$ age $<50$ years, ${ }^{16}$ TASC C and D lesions, ${ }^{19,20}$ hypertension, ${ }^{14}$ hypercholesterolemia,,${ }^{14}$ chronic renal insufficiency, ${ }^{14}$ external iliac artery (EIA) disease, ${ }^{21}$ female sex,${ }^{21}$ and smoking history. ${ }^{19}$

\section{Differences between the common and external iliac artery}

The iliac artery is subdivided as the common, external, and internal iliac or hypogastric artery. Most publications describe results after iliac artery stenting and do not differentiate between the common iliac artery (CIA) and EIA (Table 1). This may be the result of the TASC II classification. ${ }^{5}$ The TASC II classification defines aortoiliac lesions, potentially involving the distal aorta, CIA, EIA, and CFA. The limitations of this rather generic aortoiliac TASC II classification have been described previously. ${ }^{22}$ We believe that in trials investigating stents in the iliac arteries, a distinction must be made between the straight and relative immobile CIA and the tortuous and mobile EIA. Subgroups should be created according to the anatomic characteristics of the target lesion rather than by the TASC II classification. ${ }^{23}$

One of the rare studies comparing stents in the CIA and EIA showed no differences in primary patency after 1,2, and 3 years. ${ }^{24}$ Two other studies, however, found EIA stenting was an independent predictor of decreased primary patency after iliac artery PTA and stenting. ${ }^{21,25} \mathrm{~A}$ more recent study evaluating a particular self-expandable stent showed no significant difference in the patency rates at 2 years among stents placed in the CIA, the EIA, and both the CIA and EIA. ${ }^{26}$ 
Table I An overview of recent studies presenting primary patency rates of percutaneous angioplasty and bare-metal balloonexpandable (BE) or self-expandable (SE) stent placement in the iliac artery

\begin{tabular}{|c|c|c|c|c|c|c|c|c|}
\hline Author & $\begin{array}{l}\text { Year of } \\
\text { publication }\end{array}$ & $\begin{array}{l}\text { Number } \\
\text { of stented } \\
\text { lesions }\end{array}$ & $\begin{array}{l}\text { Type of } \\
\text { stents }\end{array}$ & $\begin{array}{l}\text { Iliac artery } \\
\text { segment }\end{array}$ & $\begin{array}{l}\text { TASC } \\
\text { classification }\end{array}$ & $\begin{array}{l}\text { Primary } \\
\text { patency rate } \\
\text { at I year }\end{array}$ & $\begin{array}{l}\text { Primary } \\
\text { patency rate } \\
\text { at } 3 \text { years }\end{array}$ & $\begin{array}{l}\text { Primary } \\
\text { patency rate } \\
\text { at } 5 \text { years }\end{array}$ \\
\hline Yilmaz et al ${ }^{16}$ & 2006 & 68 & $\mathrm{BE}+\mathrm{SE}$ & $\mathrm{ClA}$ & $A, B, C$ & $76 \%$ & $63 \%$ & $63 \%$ \\
\hline Balzer et $\mathrm{a}^{27}$ & 2006 & 89 & $\mathrm{BE}+\mathrm{SE}$ & $\mathrm{CIA}+\mathrm{EIA}$ & $C, D$ & NA & $89.9 \%$ & NA \\
\hline Leville et $\mathrm{a}^{28}$ & 2006 & 92 & $\mathrm{BE}+\mathrm{SE}$ & $\mathrm{CIA}+\mathrm{EIA}$ & B, C, D & NA & $76 \%$ & NA \\
\hline De Roeck et al ${ }^{29}$ & 2006 & 38 & $\mathrm{BE}+\mathrm{SE}$ & $\mathrm{CIA}+\mathrm{EIA}$ & B, C, D & $94 \%$ & $89 \%$ & $77 \%$ \\
\hline AbuRahma et al' ${ }^{12}$ & 2007 & 149 & SE & $\mathrm{CIA}+\mathrm{EIA}$ & $A, B, C, D$ & $98 \%$ & $87 \%$ & $77 \%$ \\
\hline Carreira et $\mathrm{al}^{30}$ & 2008 & 31 & SE & $\mathrm{CIA}+\mathrm{EIA}$ & NA & NA & $83 \%$ & $75 \%$ \\
\hline Gandini et $\mathrm{al}^{31}$ & 2008 & 138 & $\mathrm{BE}+\mathrm{SE}$ & $\mathrm{CIA}+\mathrm{EIA}$ & NA & NA & $90 \%$ & $85 \%$ \\
\hline Sixt et $\mathrm{al}^{32}$ & 2008 & 354 & $\mathrm{BE}+\mathrm{SE}$ & $\mathrm{CIA}+\mathrm{EIA}$ & $A, B, C, D$ & NA & NA & NA \\
\hline Kashyap et al ${ }^{3}$ & 2008 & 127 & $\mathrm{BE}+\mathrm{SE}$ & $\mathrm{CIA}+\mathrm{EIA}$ & $B, C, D$ & NA & $74 \%$ & NA \\
\hline Higashiura et $\mathrm{al}^{33}$ & 2009 & 216 & SE & $\mathrm{ClA}+\mathrm{EIA}$ & $A, B, C, D$ & NA & $93 \%$ & $91 \%$ \\
\hline Koizumi et $\mathrm{al}^{34}$ & 2009 & 296 & $\mathrm{BE}+\mathrm{SE}$ & $\mathrm{ClA}+\mathrm{EIA}$ & $A, B, C, D$ & NA & $88 \%$ & $82 \%$ \\
\hline Maurel et al ${ }^{35}$ & 2009 & 90 & $\mathrm{BE}+\mathrm{SE}$ & EIA & $A, B, C, D$ & $97 \%$ & $84 \%$ & NA \\
\hline Ozkan et $\mathrm{al}^{20}$ & 2010 & 127 & $\mathrm{BE}+\mathrm{SE}$ & $\mathrm{CIA}+\mathrm{EIA}$ & B, C, D & NA & NA & $63 \%$ \\
\hline Jaff et $\mathrm{a}^{26}$ & 2010 & 151 & SE & $\mathrm{CIA}+\mathrm{EIA}$ & NA & NA & $\begin{array}{l}91 \% \\
\text { (at } 2 \text { years) }\end{array}$ & NA \\
\hline Ichihashi et $\mathrm{al}^{36}$ & 2011 & 533 & $\mathrm{BE}+\mathrm{SE}$ & $\mathrm{CIA}+\mathrm{EIA}$ & $A, B, C, D$ & $90 \%$ & $88 \%$ & $83 \%$ \\
\hline Soga et $\mathrm{al}^{37}$ & 2012 & $2,60 I$ & $\mathrm{BE}+\mathrm{SE}$ & $\mathrm{ClA}+\mathrm{EIA}$ & $A, B, C, D$ & $92.5 \%$ & $82.6 \%$ & $77.5 \%$ \\
\hline Kordecki et al ${ }^{38}$ & 2012 & 95 & SE & $\mathrm{CIA}+\mathrm{EIA}$ & $A, B, C, D$ & $84 \%$ & $\begin{array}{l}76 \% \\
\text { (at } 2 \text { years) }\end{array}$ & NA \\
\hline Bosiers et $\mathrm{a}^{39}$ & 2013 & 147 & $\mathrm{SE}^{*}$ & $\mathrm{CIA}+\mathrm{EIA}$ & $A, B, C, D$ & $93.1 \%$ & NA & NA \\
\hline Araki et al ${ }^{40}$ & 2013 & 86 & SE & $\mathrm{CIA}+\mathrm{EIA}$ & B, C, D & NA & $\begin{array}{l}96.5 \% \\
\text { (at } 2 \text { years) }\end{array}$ & NA \\
\hline
\end{tabular}

Note: *For publications considering both BE and SE stents, only data of SE stents were displayed, if available.

Abbreviations: CIA, common iliac artery; EIA, external iliac artery; NA, not available; TASC, TransAtlantic Intersociety Consensus.

\section{Self-expanding stents and AIOD Self-expanding stent}

Most self-expanding stents are made of nitinol, an alloy of nickel and titanium. Elgiloy, a cobalt-chromium alloy, has also been used for self-expanding stents. An important feature of nitinol is its thermal shape memory and superelasticity, which means nitinol is able to return to its original shape after severe deformation. ${ }^{41,42}$ Besides being superelastic, nitinol is also biocompatible. The narrow temperature range within which nitinol's superelasticity is exhibited includes body temperature. ${ }^{43}$ Therefore, nitinol is an excellent material for a self-expanding stent design. The ability to recover their original shape without clinically relevant loss of lumen diameter is an important distinction between nitinol and stainless steel stents.

Stents have to survive pulsatility, external forces, and bending fatigue. Balloon expandable stents are sufficiently rigid to prevent the native artery from stretching and expanding due to the pulse pressure. The fatigue lifetime of nitinol far exceeds that of ordinary metals. However, extreme bending and crushing, which may be experienced under the inguinal ligament and in the popliteal or subclavian artery, may exceed the limitations of both balloon-expandable and self-expandable stents.

Nitinol stents have very low forces acting on the vessel wall (chronic outward force), but the force generated by a nitinol stent to resist compression (stiffness) increases rapidly with deflection; thus, a nitinol stent unloads its outward force when it reaches its intended diameter. Nitinol stents are able to adapt to the tortuous path of a vessel rather than forcing the vessel to straighten. Using a stiffer balloon-expandable stent may result in vessel straightening and concomitant vessel trauma ${ }^{44}$ The most important factor causing in-stent restenosis is the formation of neointimal tissue hyperplasia. ${ }^{45}$ The underlying causes of intimal hyperplasia are migration and proliferation of vascular smooth muscle cells provoked by injury, inflammation, and stretch. ${ }^{46}$

In a human cadaveric study, self-expanding stents in the CIA showed considerably lower radial expansion force than balloon-expandable stents. Moreover, precision and reproducibility of the achieved expansion was significantly lower in the self-expanding group. ${ }^{47}$ As the self-expandable stent begins to emerge from the constraint, there is a natural tendency for it to spring forward that results from several 
stent properties, including bridge design, longitudinal stiffness, and friction. Although this tendency in a selfexpandable stent can be reduced to a minimum nowadays, this potential source of inaccuracy does not exist in a balloon-expandable stent. ${ }^{43}$

A stent is a compromise, and there is no single stent that is ideal for all indications. ${ }^{44,48}$ The physical properties of balloon-expandable and self-expandable stents both exhibit superior performance in different types of arteries. Comparative studies on the performance of self-expandable and balloon-expandable stents in a clearly defined arterial segment are scarce (Table 1). Based on results from mainly in vitro studies, most physicians will prefer a balloonexpandable stent in straight, focal, and calcified lesions or lesions adjacent to the aortic bifurcation; whereas, selfexpanding stents are preferred in longer and tortuous lesions or for contralateral approaches. High-quality clinical data to support this practice are lacking, but this strategy has been advocated in many publications. ${ }^{3,15,20,27-29,31,35,36,39}$

\section{Limitations and future prospects Stent fracture}

The iliac artery, particularly the distal EIA prior to the inguinal ligament, is exposed to flexion by bending the hip joint. This may lead to stent fracture. In a series of 165 patients, a total 305 self-expandable stents were implanted in 216 iliac arteries. ${ }^{33}$ Different stent types were used, according to the preferences of the physician. During follow-up, stent

Table 2 Conclusions and level of evidence according to the Oxford Centre for Evidence Based Medicine

\begin{tabular}{|c|c|}
\hline Conclusion & $\begin{array}{l}\text { Level of } \\
\text { evidence }\end{array}$ \\
\hline $\begin{array}{l}\text { Patients treated with PTA and selective stenting for } \\
\text { iliac artery stenosis have a better outcome for } \\
\text { symptomatic success compared with patients treated } \\
\text { with primary stenting. }\end{array}$ & Ib \\
\hline $\begin{array}{l}\text { Primary stent placement for iliac artery occlusion } \\
\text { increases technical success compared with PTA. }\end{array}$ & $\mathrm{Ib}$ \\
\hline $\begin{array}{l}\text { Primary stent placement for iliac artery occlusion reduces } \\
\text { major procedural complications (predominantly distal } \\
\text { embolization) compared with PTA. }\end{array}$ & $\mathrm{Ib}$ \\
\hline $\begin{array}{l}\text { In straight, focal, and calcified iliac artery lesions or lesions } \\
\text { adjacent to the aortic bifurcation, balloon-expandable } \\
\text { stents are preferred. }\end{array}$ & 4 \\
\hline $\begin{array}{l}\text { In longer and tortuous iliac artery lesions or for contralateral } \\
\text { approaches, self-expanding stents are preferred. }\end{array}$ & 4 \\
\hline $\begin{array}{l}\text { Covered stents perform better for aortoiliac TASC C and D } \\
\text { lesions than bare stents in long-term patency and clinical } \\
\text { outcome. }\end{array}$ & $\mathrm{Ib}$ \\
\hline
\end{tabular}

Note: Data from Phillips et al. ${ }^{70}$

Abbreviations: PTA, percutaneous transluminal angioplasty; TASC, TransAtlantic Intersociety Consensus. fracture was detected in eleven of 305 stents (3.6\%). Stent fracture occurred in eleven of 222 nitinol stents $(5.0 \%)$ but not in elgiloy stents. Multivariate analysis indicated stenting for chronic occlusion as a risk factor associated with stent fracture (hazard ratio: $6.09 ; P=0.008$ ). No significant differences between stents in the CIA and EIA were observed. Reocclusion of the stented iliac artery was only detected in one of eleven iliac arteries with stent fracture. ${ }^{49}$ The primary patency rates in iliac arteries with and without fractured stents at 8 years were $90 \%$ and $91 \%$, respectively. These results are in contrast with the considerable risk of stent fractures in the femoropopliteal artery, which is associated with a higher in-stent stenosis and reocclusion rate. ${ }^{50}$

\section{Covered stents}

As described previously, the additional primary or selective use of stents improves the clinical outcome. Unfortunately, stents also have limitations, such as subacute occlusion and restenosis. Neointimal hyperplasia may grow through the struts of the stent and cause in-stent restenosis. A covered stent or stent graft is a metal stent lined with polytetrafluoroethylene (PTFE) or Dacron. Covered stents may overcome this limitation by introducing a mechanical barrier between intimal hyperplasia and the arterial lumen. The covered stent potentially also prevents migration of macrophages in the vascular wall, which are attracted by proinflammatory mediators secreted by the damaged vessel wall. These macrophages release further cytokines, metalloproteinases, and growth factors that contribute to initiating the restenotic process. ${ }^{51}$ This concept was tested using balloon-expandable stents that were covered with PTFE extending for one-half of the length of the stent. These grafts were used to treat 12 iliac artery occlusions in 12 high-risk patients. After 6 months of follow-up, the mean lumen diameter was significantly greater on the covered side than on the uncovered side. ${ }^{52}$

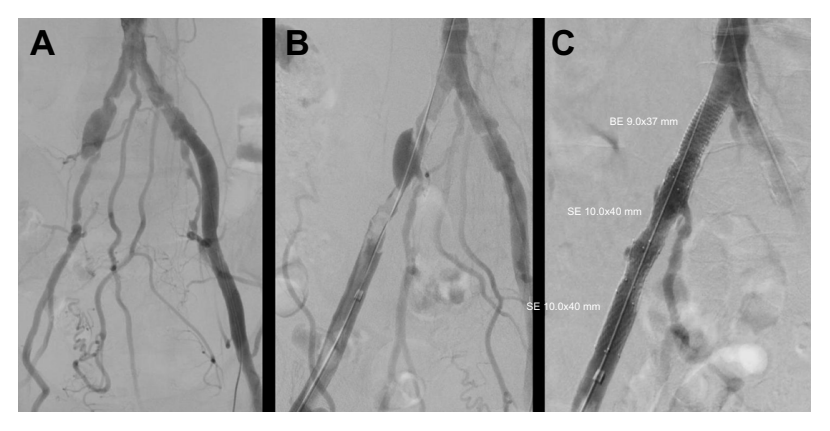

Figure I Percutaneous transluminal angioplasty of the stenosis in the right common iliac artery and occluded external iliac artery $(\mathbf{A})$ resulted in a significant residual stenosis and dissection, respectively (B). Additional stent placement resulted in technical success (C).

Abbreviations: BE, balloon-expanding; SE, self-expanding. 
A prospective evaluation of the Hemobahn PTFE-nitinol self-expanding stent (WL Gore \& Associates, Flagstaff, AZ, USA), in 61 iliac arteries and 80 femoral arteries provided primary patency rates for the iliac arteries of $98 \%$ at 6 months and $91 \%$ at 12 months. During follow-up, one early occlusion (within 30 days) of a Hemobahn stent occurred in an iliac artery. Late occlusions (30 days to 12 months) were observed in an additional five iliac arteries. ${ }^{53}$

The Cordis Covered Nitinol Stent (COVENT) study enrolled 98 patients, who received PTFE-covered nitinol stents in 60 iliac arteries and 47 superficial femoral arteries. The primary patency rates for the iliac arteries were $94.3 \%$ at 6 months and $90.7 \%$ at 12 months. Two iliac artery covered stents occluded, the first within 6 months and the second after 8 months. In-stent recurrent stenosis developed in two other iliac artery-covered stents. ${ }^{54}$

Other authors have suggested that transgraft migration of endothelial cells may result in in-stent neointimal formation, which may lead to in-stent recurrent stenosis. ${ }^{55,56}$ Another study demonstrated significantly higher 5 -year primary patency rates of $87 \%$ for predominantly self-expandable covered stents compared with 53\% for bare metal stents (BMS) in patients undergoing simultaneous common femoral artery endarterectomy and iliac revascularization. ${ }^{57}$ These results are promising, but long-term data are lacking. The explanation for the apparent benefit of covered stents in AIOD treatment is not completely clear. The decreased risk of iliac rupture may lead to improved dilatation with use of higher inflation pressure. ${ }^{57}$

Three other studies showed similar results with covered balloon-expandable stents. ${ }^{58-60}$ The Covered Versus BalloonExpandable Stent Trial (COBEST) randomly assigned 168 iliac arteries in 125 patients to receive a covered balloonexpandable stent or BMS. After 18 months of follow-up, covered stents and BMSs performed similarly in TASC B lesions; however, covered stents performed better in TASC C and D lesions than BMSs. ${ }^{61}$ The Dutch Iliac Stent Trial: Covered Balloon-Expandable versus Uncovered Balloon-Expandable Stents in the Common Iliac Artery (DISCOVER) is currently enrolling patients with a CIA occlusion or stenosis $>3 \mathrm{~cm}$, who are randomized for a balloon-expandable covered stent or BMS. ${ }^{62}$

\section{Future perspectives}

A new self-expanding interwoven nitinol stent has shown encouraging results in the popliteal artery ${ }^{63}$ This novel Supera stent (Abbott Vascular, Santa Clara, CA, USA), consists of woven nitinol wires braided in a tubular mesh configuration.
This specific configuration results in a stent that is flexible, compliant, and self-expanding and that has a very high radial resistive force. This device may perform very well in complex iliac lesions; however, the largest currently available diameter is $8 \mathrm{~mm}$.

Several promising stenting techniques are already available for noniliac arteries. In cardiology, the use of drug-eluting stents (DES) shows beneficial results. These coronary devices have been shown to be superior to BMS in tibial arteries too. ${ }^{64,65} \mathrm{~A}$ novel nitinol paclitaxel-eluting stent is available for the femoropopliteal artery. In a large randomized controlled trial, DESs showed superior 12-month event-free survival and primary patency rates compared with PTA. In the PTA group, 120 patients had acute PTA failure and underwent secondary random assignment to provisional DES or BMS. The provisional DES group exhibited superior 12-month primary patency and clinical benefit compared with the provisional BMS group. ${ }^{66}$ This particular device is not yet available for the iliac arteries, but another selfexpanding everolimus-eluting stent has been analyzed in an animal model. The iliac arteries of 24 Yucatan mini-swine were treated with the $8 \times 28 \mathrm{~mm}$ nitinol everolimus-eluting stent. Bare nitinol stents were implanted in the contralateral iliac arteries to serve as controls. During the first 6 months, local arterial stent-mediated delivery of everolimus inhibited the formation of neointimal hyperplasia. ${ }^{67}$

A drug-eluting bioresorbable vascular scaffold seems to be very promising in coronary arteries. ${ }^{68,69}$ This technology is currently being investigated in femoropopliteal lesions and may become available for the iliac artery in the future.

\section{Conclusion}

PTA and stenting is the preferred treatment modality in patients with AIOD and has been associated with satisfactory long-term results, even in challenging lesions. Primary stenting is indicated in iliac artery occlusions, while in iliac artery stenoses, selective stenting is preferred. Unfortunately, detailed information about the performance of different stent types in clearly defined iliac artery segments is limited. The unique properties of self-expanding stents make them particularly suitable for the treatment of long, tortuous, and mobile arteries, like the EIA. The most important limitation is in-stent restenosis resulting from neointimal hyperplasia. Use of covered or DESs seems promising, but more evidence is needed to finally prove these concepts (Table 2).

\section{Disclosure}

The authors report no conflicts of interest in this work. 


\section{References}

1. Selvin E, Erlinger TP. Prevalence of and risk factors for peripheral arterial disease in the United States: results from the National Health and Nutrition Examination Survey, 1999-2000. Circulation. 2004;110(6): 738-743.

2. Timaran CH, Prault TL, Stevens SL, Freeman MB, Goldman MH. Iliac artery stenting versus surgical reconstruction for TASC (TransAtlantic Inter-Society Consensus) type B and type C iliac lesions. J Vasc Surg. 2003;38(2):272-278.

3. Kashyap VS, Pavkov ML, Bena JF, et al. The management of severe aortoiliac occlusive disease: endovascular therapy rivals open reconstruction. J Vasc Surg. 2008;48(6):1451-1457.

4. Indes JE, Mandawat A, Tuggle CT, Muhs B, Sosa JA. Endovascular procedures for aorto-iliac occlusive disease are associated with superior short-term clinical and economic outcomes compared with open surgery in the inpatient population. J Vasc Surg. 2010;52(5):1173-1179.

5. Norgren L, Hiatt WR, Dormandy JA, Nehler MR, Harris KA, Fowkes FG; TASC II Working Group. Inter-Society Consensus for the Management of Peripheral Arterial Disease (TASC II). J Vasc Surg. 2007;45 Suppl S:S5-S67.

6. Goodney PP, Beck AW, Nagle J, Welch HG, Zwolak RM. National trends in lower extremity bypass surgery, endovascular interventions, and major amputations. J Vasc Surg. 2009;50(1):54-60.

7. Bosch JL, Hunink MG. Meta-analysis of the results of percutaneous transluminal angioplasty and stent placement for aortoiliac occlusive disease. Radiology. 1997;204(1):87-96.

8. Ye W, Liu CW, Ricco JB, Mani K, Zeng R, Jiang J. Early and late outcomes of percutaneous treatment of TransAtlantic Inter-Society Consensus class C and D aorto-iliac lesions. J Vasc Surg. 2011;53(6): 1728-1737.

9. Jongkind V, Akkersdijk GJ, Yeung KK, Wisselink W. A systematic review of endovascular treatment of extensive aortoiliac occlusive disease. J Vasc Surg. 2010;52(5):1376-1383.

10. Tetteroo E, van der GraafY, Bosch JL, et al. Randomised comparison of primary stent placement versus primary angioplasty followed by selective stent placement in patients with iliac-artery occlusive disease. Dutch Iliac Stent Trial Study Group. Lancet. 1998;351(9110):1153-1159.

11. Klein WM, van der Graaf Y, Seegers J, et al. Dutch iliac stent trial: long-term results in patients randomized for primary or selective stent placement. Radiology. 2006;238(2):734-744.

12. AbuRahma AF, Hayes JD, Flaherty SK, Peery W. Primary iliac stenting versus transluminal angioplasty with selective stenting. J Vasc Surg. 2007;46(5):965-970.

13. Goode SD, Cleveland TJ, Gaines PA; STAG trial collaborators. Randomized clinical trial of stents versus angioplasty for the treatment of iliac artery occlusions (STAG trial). Br J Surg. 2013;100(9):1148-1153.

14. Galaria II, Davies MG. Percutaneous transluminal revascularization for iliac occlusive disease: long-term outcomes in TransAtlantic Inter-Society Consensus A and B lesions. Ann Vasc Surg. 2005;19(3):352-360.

15. Kudo T, Rigberg DA, Reil TD, Chandra FA, Ahn SS. The influence of the ipsilateral superficial femoral artery on iliac angioplasty. Ann Vasc Surg. 2006;20(4):502-511.

16. Yilmaz S, Sindel T, Golbasi I, Turkay C, Mete A, Lüleci E. Aortoiliac kissing stents: long-term results and analysis of risk factors affecting patency. J Endovasc Ther. 2006;13(3):291-301.

17. Uher P, Nyman U, Lindh M, Lindblad B, Ivancev K. Long-term results of stenting for chronic iliac artery occlusion. J Endovasc Ther. 2002;9(1):67-75.

18. Pulli R, Dorigo W, Fargion A, et al. Early and long-term comparison of endovascular treatment of iliac artery occlusions and stenosis. JVasc Surg. 2011;53(1):92-98.

19. Kudo T, Chandra FA, Ahn SS. Long-term outcomes and predictors of iliac angioplasty with selective stenting. J Vasc Surg. 2005;42(3): 466-475.

20. Ozkan U, Oguzkurt L, Tercan F. Technique, complication, and longterm outcome for endovascular treatment of iliac artery occlusion. Cardiovasc Intervent Radiol. 2010;33(1):18-24.
21. Timaran CH, Stevens SL, Freeman MB, Goldman MH. External iliac and common iliac artery angioplasty and stenting in men and women. J Vasc Surg. 2001;34(3):440-446.

22. Bekken JA, Fioole B. Regarding "A comparison of covered vs bare expandable stents for the treatment of aortoiliac occlusive disease". J Vasc Surg. 2012;55(5):1545-1546.

23. Diehm N, Pattynama PM, Jaff MR, et al. Clinical endpoints in peripheral endovascular revascularization trials: a case for standardized definitions. Eur J Vasc Endovasc Surg. 2008;36(4):409-419.

24. Lee ES, Steenson CC, Trimble KE, Caldwell MP, Kuskowski MA, Santilli SM. Comparing patency rates between external iliac and common iliac artery stents. J Vasc Surg. 2000;31(5):889-894.

25. Powell RJ, Fillinger M, Bettmann M, et al. The durability of endovascular treatment of multisegment iliac occlusive disease. J Vasc Surg. 2000;31(6):1178-1184.

26. Jaff MR, Katzen BT. Two-year clinical evaluation of the Zilver vascular stent for symptomatic iliac artery disease. J Vasc Interv Radiol. 2010;21(10):1489-1494.

27. Balzer JO, Gastinger V, Ritter R, et al. Percutaneous interventional reconstruction of the iliac arteries: primary and long-term success rate in selected TASC C and D lesions. Eur Radiol. 2006;16(1):124-131.

28. Leville CD, Kashyap VS, Clair DG, et al. Endovascular management of iliac artery occlusions: extending treatment to TransAtlantic Inter-Society Consensus class C and D patients. J Vasc Surg. 2006;43(1):32-39.

29. De Roeck A, Hendriks JM, Delrue F, et al. Long-term results of primary stenting for long and complex iliac artery occlusions. Acta Chir Belg. 2006;106(2):187-192.

30. Carreira JM, Reyes R, Gude F, et al. Long-term follow-up of Symphony nitinol stents in iliac arteriosclerosis obliterans. Minim Invasive Ther Allied Technol. 2008;17(1):34-42.

31. Gandini R, Fabiano S, Chiocchi M, Chiappa R, Simonetti G. Percutaneous treatment in iliac artery occlusion: long-term results. Cardiovasc Intervent Radiol. 2008;31(6):1069-1076.

32. Sixt S, Alawied AK, Rastan A, et al. Acute and long-term outcome of endovascular therapy for aortoiliac occlusive lesions stratified according to the TASC classification: a single-center experience. J Endovasc Ther. 2008;15(4):408-416.

33. Higashiura W, Kubota Y, Sakaguchi S, et al. Prevalence, factors, and clinical impact of self-expanding stent fractures following iliac artery stenting. J Vasc Surg. 2009;49(3):645-652.

34. Koizumi A, Kumakura H, Kanai H, et al. Ten-year patency and factors causing restenosis after endovascular treatment of iliac artery lesions. Circ J. 2009;73(5):860-866.

35. Maurel B, Lancelevee J, Jacobi D, Bleuet F, Martinez R, Lermusiaux P. Endovascular treatment of external iliac artery stenoses for claudication with systematic stenting. Ann Vasc Surg. 2009;23(6):722-728.

36. Ichihashi S, Higashiura W, Itoh H, Sakaguchi S, Nishimine K, Kichikawa K. Long-term outcomes for systematic primary stent placement in complex iliac artery occlusive disease classified according to Trans-Atlantic Inter-Society Consensus (TASC)-II. J Vasc Surg. 2011;53(4):992-999.

37. Soga Y, Iida O, Kawasaki D, et al; REAL-AI investigators. Contemporary outcomes after endovascular treatment for aorto-iliac artery disease. Circ J. 2012;76(11):2697-2704

38. Kordecki K, Lukasiewicz A, Nowicki M, et al. Assessment of effectiveness of endovascular treatment of common and external iliac artery stenosis/occlusion using self-expanding Jaguar SM stents. Pol J Radiol. 2012;77(4):22-29.

39. Bosiers M, Deloose K, Callaert J, et al. BRAVISSIMO: 12-month results from a large scale prospective trial. J Cardiovasc Surg (Torino). 2013;54(2):235-253.

40. Araki M, Hirano K, Nakano M, et al. Two-year outcome of the self-expandable stent for chronic total occlusion of the iliac artery. Cardiovasc Interv Ther. 2013;29(1):40-46.

41. Duerig TW, Pelton AR, Stöckel D. The utility of superelasticity in medicine. Biomed Mater Eng. 1996;6(4):255-266. 
42. Chen JT, Duerig TW, Pelton AR, Stöckel D. An apparatus to measure the shape memory of properties of nitinol tubes for medical applications. $J$ Phys IV. 1995;5:1247-1252.

43. Duerig TW, Tolomeo DE, Wholey M. An overview of superelastic sten design. Minim Invasive Ther Allied Technol. 2000;9(3-4):235-246.

44. Duda SH, Wiskirchen J, Tepe G, et al. Physical properties of endovascular stents: an experimental comparison. J Vasc Interv Radiol. 2000;11(5):645-654.

45. Hoffmann R, Mintz GS, Dussaillant GR, et al. Patterns and mechanisms of in-stent restenosis. A serial intravascular ultrasound study. Circulation. 1996;94(6):1247-1254.

46. Newby AC, Zaltsman AB. Molecular mechanisms in intimal hyperplasia. J Pathol. 2000;190(3):300-309.

47. Grenacher L, Rohde S, Gänger E, Deutsch J, Kauffmann GW, Richter GM. In vitro comparison of self-expanding versus balloonexpandable stents in a human ex vivo model. Cardiovasc Intervent Radiol. 2006;29(2):249-254.

48. Dyet JF, Watts WG, Ettles DF, Nicholson AA. Mechanical properties of metallic stents: how do these properties influence the choice of sten for specific lesions? Cardiovasc Intervent Radiol. 2000;23(1):47-54.

49. Higashiura W, Sakaguchi S, Morimoto K, Kichikawa K. Stent fracture and reocclusion after placement of a single self-expanding stent in the common iliac artery and endovascular treatment. Cardiovasc Intervent Radiol. 2008;31(5):1013-1017.

50. Scheinert D, Scheinert S, Sax J, et al. Prevalence and clinical impact of stent fractures after femoropopliteal stenting. J Am Coll Cardiol. 2005;45(2):312-315.

51. Elsner M, Auch-Schwelk W, Britten M, Walter DH, Schächinger V, Zeiher AM. Coronary stent grafts covered by a polytetrafluoroethylene membrane. Am J Cardiol. 1999;84(3):335-338.

52. Marin ML, Veith FJ, Cynamon J, et al. Effect of polytetrafluoroethylene covering of Palmaz stents on the development of intimal hyperplasia in human iliac arteries. J Vasc Interv Radiol. 1996;7(5):651-656.

53. Lammer J, Dake MD, Bleyn J, et al. Peripheral arterial obstruction: prospective study of treatment with a transluminally placed selfexpanding stent-graft. International Trial Study Group. Radiology. 2000;217(1):95-104

54. Wiesinger B, Beregi JP, Oliva VL, et al. PTFE-covered self-expanding nitinol stents for the treatment of severe iliac and femoral artery stenoses and occlusions: final results from a prospective study. J Endovasc Ther. 2005;12(2):240-246.

55. Virmani R, Kolodgie FD, Dake MD, et al. Histopathologic evaluation of an expanded polytetrafluoroethylene-nitinol stent endoprosthesis in canine iliofemoral arteries. J Vasc Interv Radiol. 1999;10(4): 445-456.

56. Dolmatch B, Dong YH, Heeter Z. Evaluation of three polytetrafluoroethylene stent-grafts in a model of neointimal hyperplasia. JVasc Interv Radiol. 2007;18(4):527-534.

57. Chang RW, Goodney PP, Baek JH, Nolan BW, Rzucidlo EM, Powell RJ. Long-term results of combined common femoral endarterectomy and iliac stenting/stent grafting for occlusive disease. $J$ Vasc Surg. 2008;48(2):362-367.
58. Bosiers M, Iyer V, Deloose K, Verbist J, Peeters P. Flemish experience using the Advanta V12 stent-graft for the treatment of iliac artery occlusive disease. J Cardiovasc Surg (Torino). 2007;48(1):7-12.

59. Giles H, Lesar C, Erdoes L, Sprouse R, Myers S. Balloon-expandable covered stent therapy of complex endovascular pathology. Ann Vasc Surg. 2008;22(6):762-768.

60. Grimme FA, Spithoven JH, Zeebregts CJ, Scharn DM, Reijnen MM. Midterm outcome of balloon-expandable polytetrafluoroethylenecovered stents in the treatment of iliac artery chronic occlusive disease. J Endovasc Ther. 2012;19(6):797-804.

61. Mwipatayi BP, Thomas S, Wong J, et al; Covered Versus Balloon Expandable Stent Trial (COBEST) Co-investigators. A comparison of covered vs bare expandable stents for the treatment of aortoiliac occlusive disease. J Vasc Surg. 2011;54(6):1561-1570.

62. Bekken JA, Vos JA, Aarts RA, de Vries JP, Fioole B. DISCOVER: Dutch Iliac Stent trial: COVERed balloon-expandable versus uncovered balloon-expandable stents in the common iliac artery: study protocol for a randomized controlled trial. Trials. 2012;13:215.

63. Scheinert D, Werner M, Scheinert S, et al. Treatment of complex atherosclerotic popliteal artery disease with a new self-expanding interwoven nitinol stent: 12-month results of the Leipzig SUPERA popliteal artery stent registry. JACC Cardiovasc Interv. 2013;6(1):65-71.

64. Rastan A, Brechtel K, Krankenberg H, et al. Sirolimus-eluting stents for treatment of infrapopliteal arteries reduce clinical event rate compared to bare-metal stents: long-term results from a randomized trial. $\mathrm{J} \mathrm{Am}$ Coll Cardiol. 2012;60(7):587-591.

65. Bosiers M, Scheinert D, Peeters P, et al. Randomized comparison of everolimus-eluting versus bare-metal stents in patients with critical limb ischemia and infrapopliteal arterial occlusive disease. JVasc Surg. 2012;55(2):390-398.

66. Dake MD, Ansel GM, Jaff MR, et al; Zilver PTX Investigators. Paclitaxel-eluting stents show superiority to balloon angioplasty and bare metal stents in femoropopliteal disease: twelve-month Zilver PTX randomized study results. Circ Cardiovasc Interv. 2011;4(5): 495-504.

67. Zhao HQ, Nikanorov A, Virmani R, Schwartz LB. Inhibition of experimental neointimal hyperplasia and neoatherosclerosis by local, stentmediated delivery of everolimus. J Vasc Surg. 2012;56(6):1680-1688.

68. Dudek D, Onuma Y, Ormiston JA, Thuesen L, Miquel-Hebert K, Serruys PW. Four-year clinical follow-up of the ABSORB everolimus-eluting bioresorbable vascular scaffold in patients with de novo coronary artery disease: the ABSORB trial. EuroIntervention. 2012;7(9):1060-1061.

69. Diletti R, Farooq V, Girasis C, et al. Clinical and intravascular imaging outcomes at 1 and 2 years after implantation of absorb everolimus eluting bioresorbable vascular scaffolds in small vessels. Late lumen enlargement: does bioresorption matter with small vessel size? Insight from the ABSORB cohort B trial. Heart. 2013;99(2):98-105.

70. Phillips B, Ball C, Sackett D, et al. Levels of evidence and grades of recommendations. Available at: http://www.cebm.net/index. aspx?o=1025. Accessed March 11, 2014. Oxford, UK: Oxford Centre for Evidence-Based Medicine.
Medical Devices: Evidence and Research

\section{Publish your work in this journal}

Medical Devices: Evidence and Research is an international, peerreviewed, open access journal that focuses on the evidence, technology, research, and expert opinion supporting the use and application of medical devices in the diagnosis, treatment and management of clinical conditions and physiological processes. The identification of novel

\section{Dovepress}

devices and optimal use of existing devices which will lead to improved clinical outcomes and more effective patient management and safety is a key feature. The manuscript management system is completely online and includes a quick and fair peer-review system. Visit http://www. dovepress.com/testimonials.php to read real quotes from authors. 